\title{
Vybraná zjištění výzkumu stavu a pojetí rozvoje informačně technologických kompetencí na základních školách
}

\author{
Jiří Štípek, Petra Vaňková \\ Univerzita Karlova v Praze, Pedagogická fakulta
}

\begin{abstract}
Abstrakt: V letech 2012 a 2013 byl na pracovišti autorů tohoto sdělení řešen výzkumný projekt „Informačně technologické kompetence dětí a jejich rozvoj na základních školách“. Článek podává stručnou zprávu o pojetí tohoto projektu orientovaného na poznání stavu, struktury a tendencí rozvoje informačně technologických kompetencí a budování informačně technologické gramotnosti žáků na základních školách. Charakterizuje hlavní zjištění výzkumu ve vybraných problémových oblastech zahrnujících charakteristiky a tematické celky informatických výukových aktivit a strukturu ICT kompetencí učitelů informatických předmětů.
\end{abstract}

Kličová slova: informačně technologická výchova, informačně technologické kompetence, ICT kompetence učitelů

\section{Selected Findings of the Research on State and Conception of ICT Competencies Development in Primary and Lower Secondary Schools}

Abstract: In 2012 and 2013, the authors of this paper worked on the research project "Information Technology Competencies of Children and Their Development in Primary and Lower Secondary Schools". This article briefly reports on this project focused on examining the current state, structure and trends in development of ICT literacy education in Czech primary (ISCED 1) and lower-secondary schools (ISCED 2). It presents the key findings of the research in particular issues including characteristics and thematic units of educational ICT activities and structure of teachers' ICT skills.

Keywords: ICT literacy education, ICT skills, teacher's information technology competencies

V kontextu s rychlým vývojem společnosti vyvstávají požadavky na nově akcentované komplexy vědomostí, dovedností a postojů, jež by si měli lidé osvojovat, nebot' pro kvalitu jejich osobního a profesního života mohou nabývat srovnatelného významu s gramotností základní (např. Hoffman \& Blake, 2003; Ferrari, 2011). Mezi klíčovými kompetencemi se tak na významném místě objevily informačně technologické kompetence (dále ICT kompetence). Ty v současné době tvoří základ široce pojaté informační, resp. informačně technologické, gramotnosti a jsou implementovány v mnoha koncepčních a programových dokumentech. Jejich budování a rozvoj, který je cílem různých segmentů vzdělávání, je realizován v rámci formálních i neformálních edukačních aktivit (např. Ala-Mutka et al., 2008; Anderson, 2008; European Commission, 2010; Rambousek \& Wildová, 2008). 
Význačné postavení při zabezpečování informačně technologické výchovy a cíleném rozvoji př́slušných kompetencí, resp. kognitivních a operačních dovedností a postojů nezbytných $k$ efektivnímu využití ICT, náleží v rámci formálního či počátečního vzdělávání základním školám. I přes vzrůstající význam informální výchovy založené na zkušenostech s využíváním technologií ve společnosti, v rodině, při volnočasových aktivitách či při zábavě žáků je nutno považovat systematické edukační pưsobení v základní škole usilující o zakládání a rozvoj těchto kompetencí za nezastupitelné.

Pojetí soudobé informačně technologické výchovy by mělo podporovat rozvoj schopností, resp. kompetencí, umocňujících adaptabilitu žáků, transfer vědomostí a dovedností do nových kontextů a schopnost učit se v rychle se měnícím prostředí. Mělo by být tak rozvíjeno kritické myšlení žáků, jejich schopnost rozhodovat se a věcně argumentovat; informatické a algoritmické myšlení; schopnost řešit problémy; přispívat $\mathrm{k}$ rozvoji tvůrčího myšlení žáků a podpoře jejich kreativity. Tyto požadavky postupně vedou $v$ praxi $k$ aplikaci kompetenčního přístupu podporujícího přenositelnost znalostí a dovedností v informačně technologické výchově a jejich zohlednění přispívá k efektivnímu rozvoji př́slušných klíčových kompetencí (Ala-Mutka, 2011; European Parliament and the Council, 2006; Eurydice, 2002).

Informačně technologická výchova jako standardní součást kurikula základních škol je rysem školských systémů vyspělých zemí. Její pojetí však není jednotné a rozdíly lze mezi systémy spatřovat $v$ organizaci, rozsahu či formě př́slušných edukačních aktivit, resp. obsahu vzdělávacích oblastí, předmětů, tematických celků nebo výukových projektů. Lišit se mohou jistě též deklarace kurikulárních materiálů a jejich naplňování $v$ praxi. Nezanedbatelným faktorem jsou v tomto směru i vyučující s rozličnými didaktickými př́stupy a odbornou úrovní v oblasti ICT (Neumajer, 2007).

Výzkumy, které by se $v$ širším rozsahu primárně zabývaly stavem a pojetím informačně technologické výchovy na ZŠ v ČR, však chybí. Dosavadní výzkumné aktivity se věnují spíše využití ICT ve výuce a v práci učitele obecně. I takto koncipované studie se však, byt' okrajově, dané problematiky dotýkají a přinášejí cenná dílčí zjištění. Již ve výzkumu dopadů školení SIPVZ1 ${ }^{1}$ se objevily souvislosti ukazující na značné rozdíly v odborné úrovni učitelů informatiky (např. Neumajer, 2007). 0 obsahu informatických předmětů, resp. o různých pojetích a směrech implementace ICT do edukačních aktivit na českých základních školách, pak částečně vypovídají i př́padové studie realizované např. $v$ roce 2006 v rámci řešení mezinárodního projektu SITES². Jistým srovnáním zde mohou být též výsledky mezinárodního výzkumu ICILS33, jehož cílem bylo ožrejmit stav počítačové gramotnosti v 19 státech včetně České republiky a umožnit vzájemnou komparaci. O úrovni vzdělávacího prostředí vypovídají, $\mathrm{k}$ danému tématu, též některé výsledky výzkumu TALIS4.

\footnotetext{
SIPVZ (Státní informační politika ve vzdělávání).

SITES (Second Information Technology in Education Study - http://it.pedf.cuni.cz/sitesm2/).

ICILS (International Computer and InformationLiteracy Study - http://www.icils.cz/).

TALIS (Teaching and Learning International Survey - http://www.talis.cz/talis2008-dokumenty .html).
} 
Z dosavadních výzkumů se na problematiku stavu a pojetí informačně technologické výchovy na ZŠ v ČR výrazněji zaměřil projekt VIV06 (Rambousek et al., 2007), který jako hlavní problémy identifikoval nejasnou koncepci na státní úrovni (RVP), která na úrovni škol (ŠVP) vedla k diametrálně odlišným způsobům realizace, personálního zabezpečení příslušných předmětů a v neposlední řadě též materiálního a technického zabezpečení.

Především povinné informatické předměty a jejich realizace na ZŠ mají výrazná specifika, která do jisté míry generují některé $z$ výše naznačených problémů. $\mathrm{Na}$ rozdíl od většiny ostatních předmětů vyučovaných na ZŠ zde působí zejména faktor intenzívního vývoje v oblasti ICT. Již od devadesátých let minulého století, kdy ICT začaly pronikat do mnoha sfér života společnosti a také do školství, dochází k neustálým modernizacím, nahrazování stávajících technologií novými a ke vzniku zcela nových segmentů a platforem. Naznačené proměny se promítají nejen jako stálý tlak na inovace obsahu i koncepce povinných informatických předmětů, ale kladou i nemalé nároky na dalši vzdělávání, resp. sebevzdělávání, učitelů.

Současný stav a pojetí předmětů orientovaných na informatiku však nelze na základě dosavadních výzkumů spolehlivě charakterizovat. $Z$ hlediska školské praxe tak lze uvažovat o celém spektru př́stupů k výuce informatiky, které jsou charakterizovány na jedné straně orientací omezenou na nácvik ovládání konkrétních softwarových nástrojů a na straně druhé přistupem akcentujícím rozvoj digitální gramotnosti, kritického, tvưrčího a informatického myšlení žáků.

Uvedené skutečnosti naznačují potřebu výzkumných aktivit usilujících o poznání stavu a pojetí ICT kompetencí žáků na základních školách, ale i jejich učitelů, s dopadem výzkumných nálezů na rozpracování didaktiky informačně technologické výchovy a na zkvalitnění př́pravy učitelů v daném směru.

\section{Předmět a hlavní cíl výzkumu}

Z uvedených východisek vycházel výzkumný projekt „Informačně technologické kompetence dětí a jejich rozvoj na základních školách" (VIV13), kterým výzkumný tým navázal na projekt VIV06 (Rambousek et al., 2007). Bylo provedeno rozsáhlé šetření, jehož cílovou skupinou byli učitelé informatických předmětů na ZŠ a jejich žáci.

Předmětem výzkumné činnosti v projektu VIV13 se stala informačně technologická výchova, resp. oblast př́slušných výchovně vzdělávacích aktivit realizovaných na základních školách.

Předmět výzkumu byl konkretizován $v$ pěti problémových oblastech:

1. Výukové aktivity, v nichž jsou na ZŠ cíleně rozvíjeny ICT kompetence žáků (jednalo se o různé typy aktivit, přičemž hlavní pozornost byla věnována povinným informatickým předmětům).

2. Obsah informatických výukových aktivit (obsah byl chápán jako spektrum témat, resp. tematických celků tvořících možnou náplň informatických výukových aktivit, především pak povinných informatických předmětů). 
50 3. Stav a rozvoj ICT kompetencí žáků na ZŠ (předmětem zájmu byly kompetence různé úrovně obecnosti pojímané jako složky informačně technologické gramotnosti žáků).

4. Informačně technologické kompetence učitelů (zkoumány byly především ICT kompetence učitelů povinných informatických předmětů na pozadí úrovně kompetencí ostatních učitelů).

5. Implementace ICT a rozvoje přislušných kompetencí do výukových aktivit žáků a učitelů, do prostředí a života školy (uvažovány zde byly indikátory vstupu ICT do standardních učebních činností žáka, do standardních vyučovacích činností učitele i do vzdělávacího prostředí školy).

$\checkmark$ souladu $s$ predmětem výzkumu a problémovými oblastmi si výzkumný projekt VIV13 jako svůj hlavní cíl stanovil poznat aktuální stav, strukturu a orientaci rozvoje ICT kompetencí žáků z hlediska kurikulárních, procesuálních a organizačních aspektů.

\section{Metody a průběh výzkumu}

Při řešení projektu VIV13 byly $v$ rámci rozsáhlého explorativního šetření aplikovány empirické metody kvantitativního i kvalitativního charakteru.

Základním výzkumným nástrojem byl interaktivní grafický dotazník pro učitele 5 informatických předmětů administrovaný elektronicky, zahrnující 19 otázek a 186 dílčích dotazů. Dotazník pokrýval všech pět problémových oblastí (viz „Předmět a cíle výzkumu“). Byl koncipován tak, aby podporoval manipulaci s grafickými prvky (přiřazování, přeskupování, umist'ování) na obrazovce počítače, s možností zaznamenávat a následně vyhodnotit aktivity respondenta (Procházka, 2007).

V rámci realizace první fáze výzkumného šetření VIV13 byl v březnu 2013 distribuován dotazník pro učitele na 3500 náhodně vybraných školách. Výzva k vyplnění byla za účelem zvýšení návratnosti opakována v dubnu.

Výzkumná data byla v této fázi získána od 1183 respondentů, zastupujících jednotlivé základní školy (typicky jeden respondent na školu), kteří dotazník vyplnili ve všech položkách nebo $v$ jejich převážné části. Vzhledem $\mathrm{k}$ tomu, že jeden respondent zastupoval jednu školu, přestavuje návratnost dotazníku cca 34 \%.

Ve druhé fázi řešení projektu VIV13 byla aplikována metoda ankety. Anketa byla orientovaná na přihlášené zájemce o užší participaci ve výzkumu. Osloveno bylo takto 167 učitelů informatických předmětů, z nichž 84 vyjádřilo svá stanoviska a zkušenosti s informačně technologickou výchovou a s rozvojem př́slušných kompetencí žáků základních škol. Přihlášení zájemci o užší participaci ve výzkumu zabezpečili též administraci dotazníku určeného jejich žákům. Žákovský dotazník se sedmi komplexními otázkami zahrnujícími celkem 16 dílčích dotazů vyplnilo 2173 žáků. Jako poslední empirická metoda byla aplikována metoda př́padových studií implementace ICT do výukových aktivit a do školního vzdělávacího prostředí. Uskutečnilo se

5 Dotazník je dostupný z http://it.pedf.cuni.cz/dotaznik2013/index.php?cislo=1. 
6 případových studií spočívajících v prohlídce školy, pozorování ve výuce, besedě s žáky a rozhovoru s učitelem informatických předmětů.

Přestože rozsah zkoumaného vzorku v rámci realizace dotazníkové metody byl značný, nebylo možné vzhledem k principu dobrovolnosti vyplnění dotazníku zajistit plnou reprezentativnost vzorku. Stejně tak tomu bylo i v př́padě ankety a žákovského dotazníku, nebot' výběr respondentů zde byl primárně založen na zájemcích o participaci na výzkumném šetření. Dále uvedené poznatky je proto možné vztahovat k danému vzorku respondentů, přičemž k jejich zobecňování je nutno přistupovat uvážlivě.

\section{Vybrané výsledky výzkumu}

V následující části tohoto sdělení budou prezentována vybraná základní zjištění prvé fáze výzkumného projektu VIV13 (dotazník pro učitele). Uvedeny budou i relevantní souvislosti se zjištěními projektu VIV06 (Rambousek et al., 2007; Procházka et al., 2010).

Výzkumný vzorek dotazníku pro učitele tvořilo 1183 učitelů informaticky orientovaných předmětů. 6 Byla $v$ něm zastoupena $v$ podstatě rovnoměrně obě pohlaví, konkrétně pak muži tvořili $46 \%$ a ženy 54 \% respondentů. V porovnání s výzkumem VIV06 lze registrovat mírný posun ve prospěch žen (51 \% mužů, 49 \% žen). Toto rozložení odpovídá specifice učitelů sledovaných informatických předmětů, přestože dle Čsú (2012) z hlediska celkového počtu 57815 učitelů základních škol tvořili v roce 2012 muži pouze $16 \%$ a ženy $84 \%$.

Geografické rozložení vzorku respondentů dotazníku pro učitele bylo velmi rovnoměrné a odpovídalo s dostatečnou přesností celkovému rozložení základních škol v České republice, a to jak po stránce zastoupení počtu škol v jednotlivých krajích, z hlediska velikosti lokality, v níž se školy respondentů nacházely, tak i co do velikosti jednotlivých škol respondentů reprezentovaných počtem žáků.

\subsection{Charakteristiky informatických výukových aktivit}

První problémová oblast výzkumného projektu se týkala charakteristik výukových aktivit, v nichž jsou na základních školách cíleně rozvíjeny ICT kompetence žáků, resp. budována jejich informačně technologická gramotnost. V rámci příslušné části dotazníku pro učitele se respondenti vyjadřovali k různým typům informatických výukových aktivit realizovaných na jejich škole.

Výsledky ukazují, že informatické výukové aktivity se na základních školách realizují v širším spektru v podobě: povinných i nepovinných informatických předmětů, zařazování informatických témat do jiných předmětů, využívání ICT v jiných předmětech i realizace informaticky orientovaných projektů, jak je uvedeno v následující tabulce (tabulka 1).

6 Stručné shrnutí předběžných výsledků zaslané respondentům je dostupné na adrese: http:// it.pedf.cuni.cz/gacr2013/prehledVysledku.pdf. 
52 Na 1. stupni ZŠ probíhají v různé míre všechny hlavní typy informatických výukových aktivit. Nejčastěji ( 91 \%) jsou realizovány formou povinného předmětu. Poměrně často se vyskytuje i využivání digitálních technologií v neinformatických předmětech (75\%). Ostatní typy aktivit jsou na 1 . stupni Zš zastoupeny již v menší míre. Na 2. stupni ZŠ celkově dochází k nárůstu u všech typů informatických výukových aktivit a u povinných informatických předmětů dosahuje téměř $100 \%$.

Tabulka 1 Relativní četnosti rozložení voleb respondentů z hlediska informatických výukových aktivit

\begin{tabular}{lcc}
\hline Informatické výukové aktivity & 1. stupeň (\%) & 2. stupeň (\%) \\
\hline Informatické předměty povinné & 90,5 & 97,3 \\
Informatická témata v rámci jiných předmětů & 25,9 & 44,9 \\
Informaticky orientované projekty & 14,4 & 35,5 \\
Využívání ICT v různých předmětech & 75,0 & 84,0 \\
Nepovinné informatické předměty nebo kroužky & 34,0 & 40,3 \\
\hline
\end{tabular}

Za nejdůležitější z hlediska systematického rozvoje příslušných kompetencí žáků základních škol lze v současné době považovat povinné informatické předměty. Proto byla otázka doplněna o blok, kde respondenti uváděli týdenní hodinovou dotaci povinných informatických předmětů $v$ jednotlivých ročnících.

Hodinová dotace povinného informatického předmětu vypovídá, že povinný předmět na 1. stupni ve většině základních škol začíná až od 5 . ročníku, a to při dotaci jedné hodiny týdně. Hodinová dotace povinného předmětu na 2. stupni je v celkovém pohledu nejvyšší v 6 . ročníku a potom pozvolna klesá. Ve srovnání $s 1$. stupněm se výrazněji objevuje dotace dvou hodin týdně, a to ve všech ročnících v podobné míře (tabulka 2).

Tabulka 2 Relativní četnosti rozložení voleb respondentů z hlediska týdenního počtu hodin povinných informatických předmětů

\begin{tabular}{lccccccccc}
\hline & \multicolumn{10}{c}{$(\%)$} \\
\cline { 2 - 9 } & 1. roč. & 2. roč. & 3. roč. & 4. roč. & 5. roč. & 6. roč. & 7. roč. & 8. roč. & 9. roč. \\
\hline 1 hod. & 3,0 & 4,5 & 12,0 & 31,6 & 82,3 & 74,3 & 58,9 & 51,0 & 48,2 \\
2 hod. & & & & 0,9 & 2,9 & 12,9 & 12,3 & 12,8 & 13,9 \\
3 hod. & & & & & & 0,2 & 1,1 & 1,8 & 2,2 \\
\hline
\end{tabular}

Na první pohled překvapivě působí výsledek informaticky orientovaných projektů. Na téměř dvou třetinách škol (64\%) se s nimi žáci na druhém stupni vůbec nesetkají. Přestože $v$ odborné i laické veřejnosti panuje především díky dobré informovanosti značné povědomí o výukových projektech, do nichž jsou funkčně zapojovány informační technologie, realita škol zaostává za mediálním obrazem, který kolem pro- 
jektů v posledních letech vznikl. Pokud jde o využívání ICT v různých předmětech, je vidět, že na 16 \% škol se mimo informatické předměty informační technologie vůbec nevyužívají. Celkově na 14 \% škol se žáci na 2 . stupni nesetkají s informaticky orientovanými projekty, nerealizují informatická témata $v$ rámci jiných předmětů, a dokonce ani nevyužívají ICT v různých předmětech. Naopak na 26 \% škol se žáci na 2. stupni setkávají se všemi třemi uvedenými typy aktivit.

\subsection{Obsah informatických výukových aktivit}

Druhá problémová oblast byla zaměřena na obsah informatických aktivit. Uvažováno zde bylo spektrum témat, resp. tematických celků tvořících možný obsah povinných informatických předmětů. Dotazník pro učitele pokrýval oblast šesticí otázek, v jejichž rámci se respondenti z různých hledisek vyjadřovali k seznamu 14 tematických celků.

Záměrem výzkumného týmu bylo, aby seznam odpovídal RVP ZV, ale současně umožňoval identifikovat, $v$ jakých směrech jeho pojetí základní školy modifikují či překračují. Výsledný seznam (viz tabulka 3) tak obsahuje tematické celky standardní i tematické celky reflektující aktuální stav oblasti ICT a soudobé požadavky na rozvoj ICT kompetencí žáků.

\section{Význam tematických celků informatických předmětů}

V souvislosti s obsahem povinných informatických předmětů se respondenti nejprve vyjadřovali k významu jednotlivých tematických celků, který, dle jejich názoru, mají pro rozvoj informačně technologické gramotnosti žáků základních škol. Význam respondenti vyjadřovali tažením posuvníku na stupnici $0-100$, přičemž pro některé statistické analýzy a shrnující výstupy byla takto získaná data kategorizována do 10 kategorií.

Zjištěné výsledky jsou shrnuty v následující tabulce (tabulka 3), kde jsou jednotlivé tematické celky roztříděny do 5 skupin, přičemž určujícím kritériem pro jejich zařazení byly hodnoty dolního a horního kvartilu kategorizovaných dat. Hodnoty kvartilů jsou vyjádřeny pruhovými grafy, v nichž na levém okraji je uvedena hodnota dolního kvartilu a na pravém okraji hodnota horního kvartilu.

Obsazení prvních dvou kategorií „nejvýznamnější“ a „velmi významné“ ukazuje přetrvávající pojetí informačně technologické výchovy, které lze stručně charakterizovat jako budování základních uživatelských dovednosti s výrazným zastoupením činností s kancelářskými aplikacemi a doplněné o dnes diskutované etické, bezpečnostní a právní aspekty.

Poslední kategorie „málo významné“ obsahuje celky, které v celém seznamu reprezentují informatiku. Od roku 2006 (VIV06) nedošlo v tomto ohledu ke změně. To $v$ důsledku už jen dokresluje přetrvávající uživatelské pojetí informačních technologií, k nimž je na našich školách přistupováno obvykle jako k prostředku či nástroji, který je potřeba umět pouze ovládat (Rambousek et al., 2013). 
54 Tabulka 3 Kategorie tematických celků podle hodnocení jejich významu respondenty

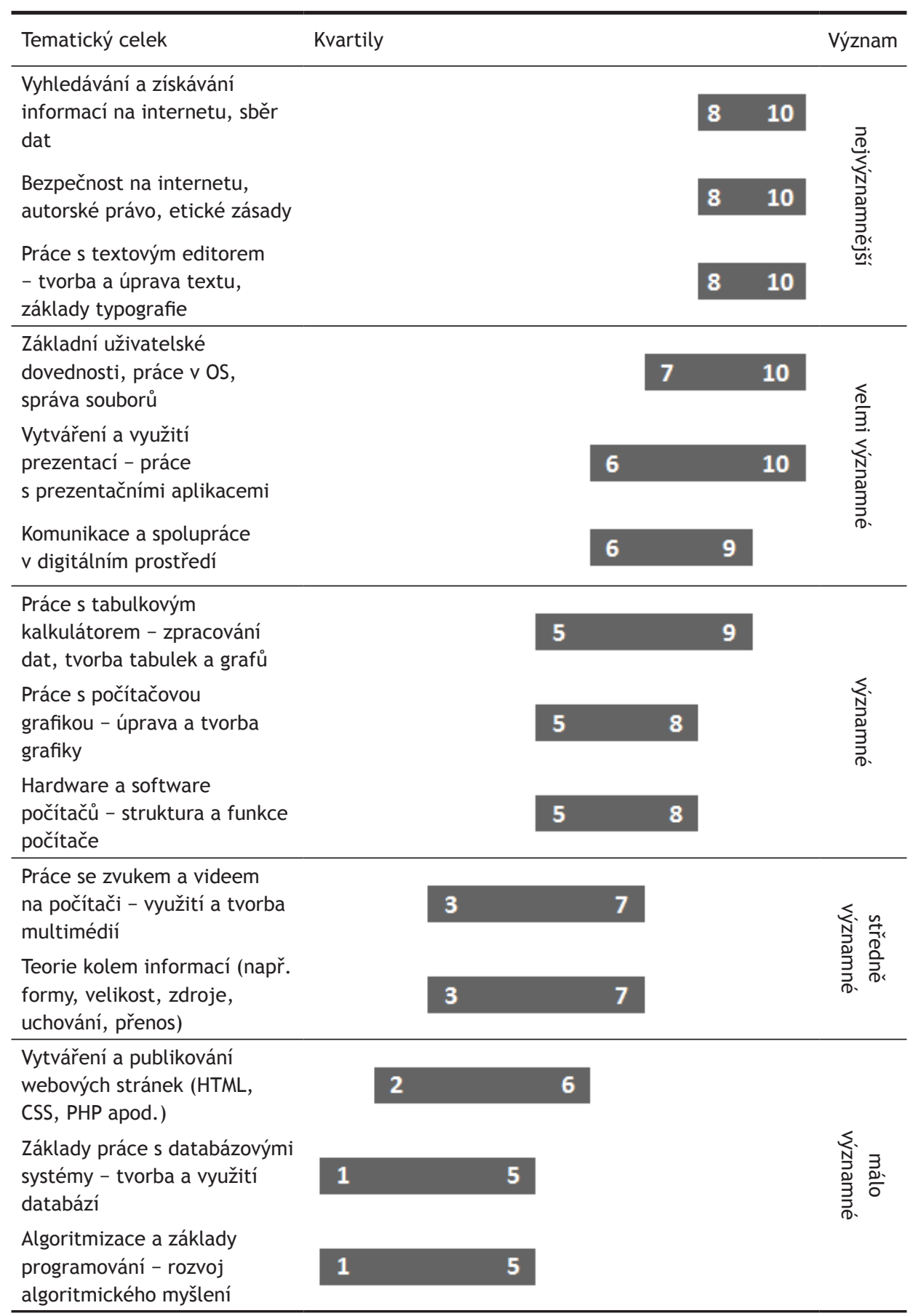




\section{Výběr klíčových tematických oblastí}

V dalši otázce byla respondentům navozena hypotetická situace, že je nutno výrazným zpưsobem zmenšit hodinovou dotaci, a tudíž značně omezit obsah výuky povinného informatického předmětu. Respondenti zde vybírali nejvýše 5 tematických celků, které by $v$ povinném předmětu zachovali, ale současně i nejvýše 5 , které by určitě obětovali.

Volbu respondenti prováděli přetažením odpovídajícího ikonického symbolu položky seznamu ze zásobníku do jednoho ze dvou boxů označených „zachovat“, resp. „obětovat“. $Z$ celkově 14 položek seznamu tedy respondenti mohli roztř́idit nejvýše 10 (nejvýše 5 zachovat a nejvýše 5 obětovat), tj. nejméně 4 položky byli nuceni ponechat v zásobníku. Shrnutí získaných výsledků je vyobrazeno na následujícím grafu (obrázek 1), kde jsou jednotlivé položky seznamu seřazeny dle zastoupení volby „zachovat“.

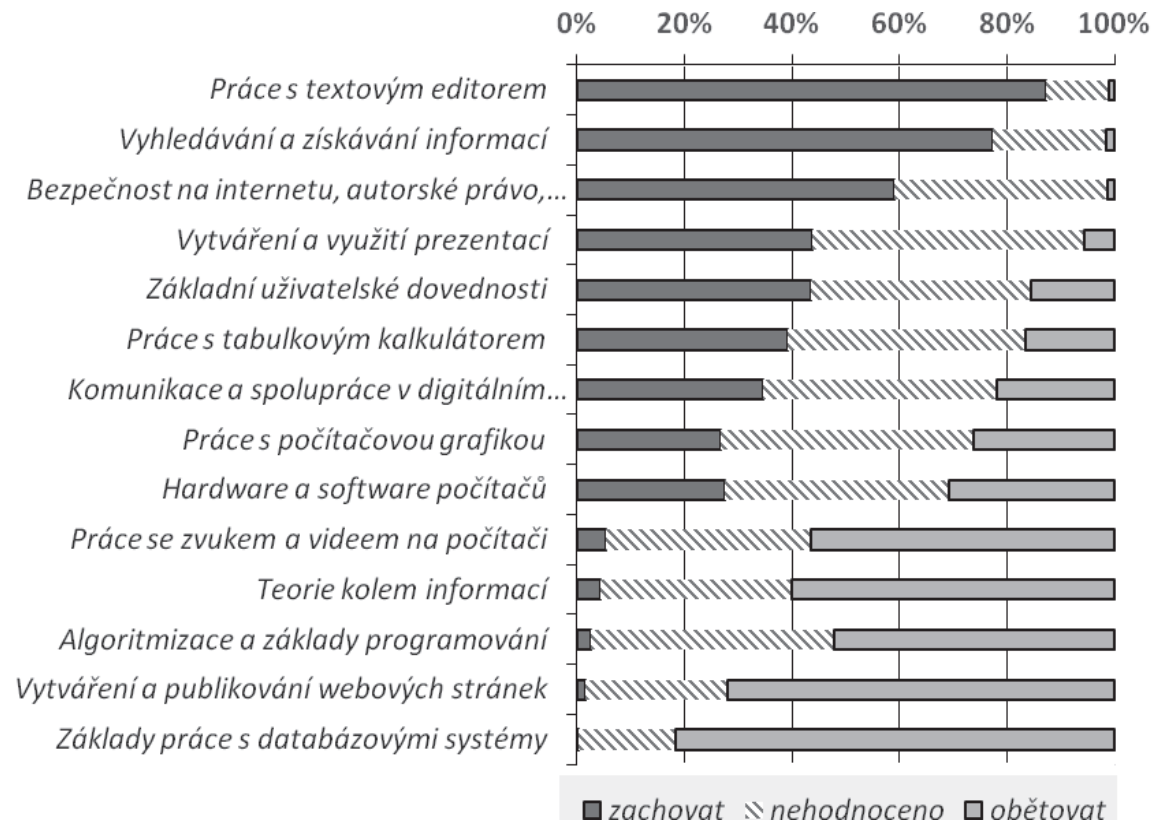

Obrázek 1 Souhrnný přehled rozložení voleb respondentů u jednotlivých tematických celků

V souladu se smyslem otázky byla analýza dat vedena snahou identifikovat skupinu témat, kterou je možné z pohledu respondentů označit za kličcovou, a skupinu, kterou je možné ve stejném smyslu označit za postradatelnou. Během analýzy se ukázalo, že se mezi respondenty objevuje několik názorových proudů a $v$ celkovém pohledu tak lze za klíčové označit pouze 3 tematické celky. Naopak skupina postradatelných celků v podstatě zřetelně vyplynula již ze základních statistik (viz obrázek 1).

Za klíčové tematické celky pro rozvoj ICT kompetencí žáků základních škol respondenti považují: 
56 - práci s textovým editorem - tvorba a úprava textu, základy typografie;

- vyhledávání a získávání informací na internetu, sběr dat;

- bezpečnost na internetu, autorské právo, etické zásady.

Uvedenou trojici samozřejmě nelze chápat jako jádro informačně technologické výchovy, ale skutečně pouze jako skupinu celků, které jsou považovány za klíčové, bez ohledu na vzájemné vazby mezi nimi či vazby k jiným celkům. Jde o celky, které mají své pevné místo např́č různými pojetími či přístupy respondentů $k$ informačně technologické výchově.

Za celky z opačné strany významového spektra, tedy ty, které jsou z hlediska rozvoje př́ślušných kompetencí žáků považovány za postradatelné, respondenti považují:

- algoritmizace a základy programování - rozvoj algoritmického myšlení;

- práce se zvukem a videem na počítači - využití a tvorba multimédií;

- teorie kolem informací (např. formy, velikost, zdroje, uchování, přenos);

- vytváření a publikování webových stránek (HTML, CSS, PHP apod.);

- základy práce s databázovými systémy - tvorba a využití databází.

Obsazení obou skupin (klíčové, postradatelné) podává hrubý obraz o chápání významu dílčích tematických celků učiteli, a tím v hrubých rysech i o pojetí informačně technologické výchovy na základních školách. Další výstupy projektu, které vzhledem $\mathrm{k}$ omezenému prostoru článku nebylo možné představit, ukazují, že v sousloví „informačně technologická výchova“ je ve vztahu k realitě českých škol slovo „výchova“ zcela na místě. Vezmeme-li v úvahu jiné předměty, jako jsou např. fyzika, chemie či matematika a jejich pojetí, zejména jejich orientaci na př́slušnou vědní disciplínu, a srovnáme je s pojetím informatických předmětů, dojdeme k závěru, že $v$ současné informačně technologické výchově na základních školách se pojetí informatiky jako vědy téměř nepromítá.

\section{Obsah a návaznost informatických výukových aktivit}

Další otázka dotazníku se orientovala na návaznosti, resp. pořadí tematických celků z hlediska procesu rozvíjení sledovaných kompetencí žáků. Respondenti z nabízených témat vybírali ta, kterým se ve výuce věnují, a současně je umíst'ovali na „časovou osu“ v pořadí, v němž je probírají. Cílem dotazu bylo jednak zjistit, která témata jsou vyučována, jednak vysledovat, jaké prerekvizity, resp. postrekvizity jsou jednotlivým tématům přisuzovány.

Analýza získaných dat se v první fázi orientovala na otázku, které z nabízených celků seznamu jsou běžnou součástí obsahu povinných informatických předmětů na základních školách a které jsou ve stejném smyslu spíše okrajové.

Slovem „obvyklé“ výzkumný tým označil ty tematické celky, které jako součást obsahu vlastní výuky vybralo alespoň $80 \%$ respondentů (všechny ostatní celky v tomto směru nepřesáhly $60 \%$ ). Následující přehled je uvádí seřazené sestupně podle počtu respondentů, kteří je vybrali.

- Práce s textovým editorem - tvorba a úprava textu, základy typografie

- Bezpečnost na internetu, autorské právo, etické zásady 
- Vyhledávání a získávání informací na internetu, sběr dat

- Hardware a software počítačů - struktura a funkce počítače

- Vytváření a využití prezentací - práce s prezentačními aplikacemi

- Práce s tabulkovým kalkulátorem - zpracování dat, tvorba tabulek a grafů

- Základní uživatelské dovednosti, práce $v$ OS, správa souborů Slovem „okrajové“ výzkumný tým označil ty tematické celky, které jako součást obsahu vlastní výuky vybralo nejvýše 20 \% respondentů. Takto stanovenému kritériu odpovídala pouze trojice celků. V následujícím přehledu jsou „okrajové“ celky řazeny stejným způsobem jako celky „obvyklé“.

- Vytváření a publikování webových stránek (HTML, CSS, PHP apod.)

- Algoritmizace a základy programování - rozvoj algoritmického myšlení

- Základy práce s databázovými systémy - tvorba a využití databází

Ve skupině „okrajových“ celků je pozoruhodné především postavení Algoritmizace a základů programování, kdysi dominantní a cílové dovednosti v oblasti počítačového vzdělávání. $Z$ hlediska geneze zařazování počítačových technologií do výuky na školách dokládají získané výsledky transformaci pojetí založeného na klíčovém významu algoritmizace a programování směrem $\mathrm{k}$ pojetí založenému na uživatelském zvládnutí základních aplikací a nástrojů.

Ve druhé fázi byla analýza zaměřena na pořadí, ve kterém jsou tematické celky na ZŠ probírány. Ukázalo se, že $v$ datech je skryto několik variant pořadí, a nemá tedy smysl stanovovat jediné výsledné pořadí např. podle mediánů či jiných statistik nebo kritérií.

Pro ilustraci uvažujme dvě podskupiny respondentů, kdy první upřednostňuje na začátku teoretická témata a druhá naopak témata praktická. Výsledkem by pak $\checkmark$ podstatě byla dvě výsledná pořadí. Snaha stanovit v takové situaci jediné výsledné pořadí by pak byla jakýmsi průměrováním obou hypotetických variant a v důsledku by neodrážela názor žádné ze dvou podskupin, resp. žádného respondenta.

Pro identifikaci variant pořadí byla aplikována shluková analýza. Ta proběhla na redukované datové matici, která neobsahovala data odpovídající celkům výše označeným jako „okrajové“. Výsledkem bylo nalezení celkem 11 variant, z nichž 5 bylo z hlediska počtu respondentů marginálních (méně než $4 \%$ ). U zbývajících 6 shluků se počet respondentů pohyboval v rozmezí od $10 \%$ do $21 \%$. Z dalších analýz byly marginální shluky vyloučeny a pozornost byla věnována 6 shlukům, které $v$ součtu reprezentovaly 79 \% respondentů. Vedle rozboru nalezených variant byla stejně jako $\checkmark$ rámci projektu VIV06 provedena analýza založená na vztazích mezi jednotlivými tematickými celky. Konkrétně se jednalo o hledání návazností celků, kdy rozhodující není absolutní pozice ve shlucích, ale vztahy „před“ a „po“, které lze sledovat alespoň u $5 \mathrm{z}$ celkem 6 zkoumaných pořadí.

Vedle zmíněných vztahů „před“ a „po“ se nabízelo i použití termínů „prerekvizita“ a „postrekvizita“, avšak tyto termíny kromě pořadí implikují i jistou obsahovou závislost tematických celků. Takový vztah ovšem mezi některými tématy nebyl, a použití termínů „prerekvizita“ a „postrekvizita“ by proto nebylo vždy adekvátní. 
Výstupy analýzy byly syntetizovány ve formě následujícího přehledu (tabulka 4), který prezentuje shodné aspekty zkoumaných variant ve smyslu pořadí tematických celků.

Tabulka 4 Shrnutí společných znaků nalezených variant pořadí tematických celků

\begin{tabular}{|c|c|c|}
\hline $\begin{array}{l}\text { Základní uživatelské } \\
\text { dovednosti }\end{array}$ & Hardware a software počítačů & \\
\hline Práce s textovým editorem & $\begin{array}{l}\text { Komunikace a spolupráce } \\
\text { v digitálním prostředí }\end{array}$ & $\begin{array}{l}\text { Bezpečnost na internetu, } \\
\text { autorské právo, etika }\end{array}$ \\
\hline Práce s počítačovou grafikou & Teorie kolem informací & $\begin{array}{l}\text { Vyhledávání a získávání } \\
\text { informací }\end{array}$ \\
\hline Vytváření a využití prezentací & $\begin{array}{l}\text { Práce s tabulkovým } \\
\text { kalkulátorem }\end{array}$ & \\
\hline $\begin{array}{l}\text { Práce se zvukem a videem na } \\
\text { počítači }\end{array}$ & & \\
\hline
\end{tabular}

Přehled představuje čtyři skupiny celků (oddělených silnou čarou), které z hlediska pořadí následují po sobě nejméně $v$ pěti ze všech šesti variant. $V$ rámci skupin nemá pořadí (zleva doprava) žádný význam. Pouze u druhé skupiny, která má dva rádky, celky prvního řádku předcházejí celkům druhého raádku ve čtyřech ze šesti variant pořadí.

Všechny varianty pořadí se ideálně shodují v celku Práce se zvukem a videem na počítači, který je u všech variant vždy posledním. Jako první jsou pak v pěti variantách probírány Základní uživatelské dovednosti, práce $v$ OS, správa souborů a Hardware a software počítačù. Druhá a třetí skupina, $v$ jejichž rámci je pořadí ve variantách poměrně proměnlivé, indikují, že Vytváření $a$ využití prezentací a Práce $s$ tabulkovým kalkulátorem jsou probírány ke konci, resp. $v$ drtivé většině př́padů až po celcích skupiny druhé. Podobný výsledek analýzy návazností byl očekáván, a to především v souvislosti s první skupinou, protože základní uživatelské dovednosti jsou nutnou podmínkou pro zvládnutí dalších celků. Téma týkající se hardwaru naopak představuje tradičně úvodní téma.

Poněkud překvapivě pưsobí návaznost Teorie kolem informací a Vyhledávání a získávání informací, u nichž lze předpokládat jistou logickou návaznost. Ta se však objevuje pouze u dvou variant pořadí, zatímco u ostatních je mezi nimi řada jiných témat, nebo je jejich pořadí dokonce opačné.

Ve srovnání s výsledky VIV06 lze sledovat výrazně větší rozdíly mezi pořadími a současně menší míru respektování logických návazností. Výsledky naznačují, že rada respondentů nedostatečně přihlíži $\mathrm{k}$ souvislostem mezi tematickými celky a koncipuje svou výuku tak, jako by byly tematické celky zcela izolovanými jednotkami bez souvislostí. Z toho lze pak dovodit i celkové pojetí informatických aktivit, resp. realizovaných tematických celků, protože jediným možným způsobem, jak 
realizovat výuku s minimálním respektem k návaznostem a souvislostem, je silná orientace na aplikace a uživatelský přistup.

\subsection{Struktura informačně technologických kompetencí učitelů}

V oblasti ICT kompetencí učitelů bylo primárním cílem zmapovat jejich úroveň z různých hledisek. Především se jednalo o zjištění úrovně ICT kompetencí respondentů a o zjištění jejich názorů na kompetence jejich kolegů ve škole. Sekundární cíl zjišt’ování pak byl orientován na minimální, tj. ještě přijatelnou, úroveň ICT kompetencí (odbornou úroveň) učitelů informatických předmětů. Zjišt’ování ve smyslu primárního cíle bylo provedeno metodou autoevaluačních deklarací respondentů a evaluací kompetencí kolegů z jejich školy. Ve vztahu k sekundárnímu cíli pak respondenti vyjadřovali názor na minimální úroveň ICT kompetencí, kterou by měl disponovat každý učitel informatických předmětů.

Strukturu ICT kompetencí učitelů nebylo možno vzhledem k pojetí a rozsahu výzkumu zjišt’ovat výkonovým testem, kromě toho nebylo primárním záměrem testovat vědomosti a dovednosti učitelů. Použita zde byla proto technika řešení podnětové situace a dále technika autoevaluace a evaluace, jejíž výsledky byly podporovány dalšími otázkami. Na základě publikovaných výsledků některých šetření (např. Peterka, 2005), v nichž byla srovnávána validita deklarované a objektivně ověřované úrovně ICT kompetencí, lze takto získané výsledky, a to i s ohledem na množství respondentů, považovat při vnímání jejich charakteru a mírné tendence nadhodnocovat sebehodnocení za dostatečně vypovídající.

\section{Stupně rozvoje technologických dovedností učitelů}

Respondentům byla předložena šestistupňová škála vyjadřující jednotlivé úrovně rozvoje ICT kompetencí učitele prostřednictvím způsobů využívání technologií ve výuce se zřetelnou gradační dynamikou:

Stupeň 1 - Učitel ICT technologie dostatečně neovládá a nevyužívá je ve své výuce, ani při přípravě na výuku.

Stupeň 2 - Učitel s podporou technologické asistence občas využívá prezentace, výukové programy, aplikace nebo hry.

Stupeň 3 - Učitel ovládá běžné funkce kancelářského software a internetu (e-mail, www prohlížeč). Při vlastní výuce tyto kompetence využívá jen málo.

Stupeň 4 - Učitel používá širší soubor softwaru a on-line služeb a je schopen např. vytvářet prezentace, tabulky nebo jednoduché www stránky. Tyto aktivity začleňuje též do své výuky.

Stupeň 5 - Učitel je schopen využívat ICT tvořivým způsobem k podpoře výuky, získávat, upravovat či vytvářet výukové materiály a aplikace a přizpůsobovat je potřebám žáků.

Stupeň 6 - Učitel je schopen ICT využívat, spravovat i rozvíjet a je schopen se adaptovat na nové technologie. Žáky vede k používání pokročilých programů a aplikací i k tvorbě vlastních materiálů. 
60 Úkolem respondentů bylo vyjádřit prostřednictvím škály odpovědi na tř̌i následující dotazy:

1. Jaký stupeň lze v průměru přisoudit učitelům informatických předmětů Vaší školy? (INF_ACT)

2. Jaký stupeň by měl nejméně mít učitel informatických předmětů? (INF_MIN)

3. Jaký stupeň ICT kompetencí přisuzujete nyní sobě? (RESP_ACT)

Tabulka 5 Relativní četnosti rozložení voleb respondentů (VIV06 a VIV13)

\begin{tabular}{lccccccc}
\hline & \multirow{2}{*}{$\begin{array}{c}\text { Zkratka } \\
\text { otázky }\end{array}$} & \multicolumn{6}{c}{ Relativní četnost vybraného stupně (\%) } \\
\cline { 3 - 7 } & stp. 1 & stp. 2 & stp. 3 & stp. 4 & stp. 5 & stp. 6 \\
\hline \multirow{3}{*}{ VIV06 } & INF_ACT & 1 & 2 & 10 & 28 & 40 & 19 \\
& INF_MIN & 1 & 0 & 5 & 25 & 42 & 26 \\
& RESP_ACT & 0 & 0 & 9 & 24 & 48 & 20 \\
\hline \multirow{2}{*}{ VIV13 } & INF_ACT & 0 & 1 & 5 & 14 & 51 & 29 \\
& INF_MIN & 1 & 1 & 2 & 23 & 45 & 28 \\
& RESP_ACT & 0 & 0 & 2 & 13 & 53 & 32 \\
\hline
\end{tabular}

Základní situaci v rozložení voleb respondentů a srovnání s výsledky VIV06 prezentuje souhrnná frekvenční tabulka pro všechny dílčí dotazy (tabulka 5). Ve výzkumu VIV06 se jednalo celkem o 930 respondentů a ve výzkumu VIV13 o 1183 respondentů. Údaje o četnosti jsou $z$ důvodu srovnatelnosti $v$ tabulce uváděny relativně.

První dílčí dotaz (INF_ACT) zjištoval, jaký stupeň rozvoje ICT kompetencí lze $\checkmark$ průměru přisoudit učitelům informatických předmětů na škole respondenta. Medián i modus voleb ve VIV06 i VIV13 odpovídá pátému stupni škály. Za uplynulých 6 let však došlo k nárůstu voleb pátého stupně ze 40 \% na 51 \%. Nejvyšší nabízená úroveň (6), kterou lze označit za částečně produkční, rovněž zaznamenala nárůst, a to $z 19$ na $29 \%$.

$\mathrm{Na}$ druhou stranu rozložení voleb uvedených ve frekvenčních tabulkách stále ukazuje nezanedbatelné obsazení nižších stupňů škály ( 3 a 4; 5 \% a 14\%), které však u učitelů informatických předmětů není možné považovat za dostatečné. Celkové srovnání VIV13 a VIV06 a zřetelný pozitivní posun k vyšším stupňům ICT kompetencí učitelů informatických předmětů je patrný z grafu (obrázek 2).

Druhý dílči dotaz zjišt'oval, jaký stupeň rozvoje ICT kompetencí nejméně by měl mít učitel informatických předmětů obecně (INF_MIN). I zde medián a modus směřují k pátému stupni škály a ve srovnání s VIV06 celkově nedošlo v rozložení voleb respondentů ke statisticky významným změnám.

Zajímavá zjištění v rámci analýzy VIV13 přinesl pohled, který se vyjádřením respondentů v otázce minimální požadované úrovně (INF_MIN) věnoval hodnocení aktuálního stavu na jejich škole (INF_ACT). Respondenti, kteří hodnotili současnou úroveň kompetencí svých kolegů pomocí nižších stupňů škály (3 a 4), ve 


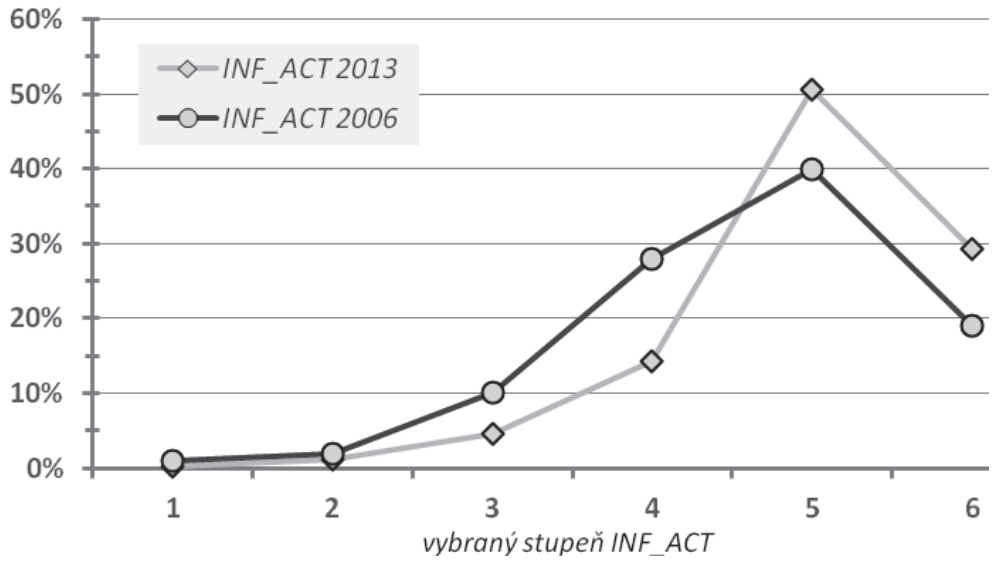

Obrázek 2 Srovnání ICT kompetencí učitelů VIV13 a VIV06

větší míře deklarovali i nižší požadavky na minimální úroveň učitelů informatických předmětů obecně. Pro ilustraci je v následujícím grafu (obrázek 3) uvedeno srovnání rozložení voleb v otázce minimální požadované úrovně pro podskupinu respondentů, kteří současný stav hodnotili na stupni 3 , a podskupinu, která jej hodnotila na stupni 6.

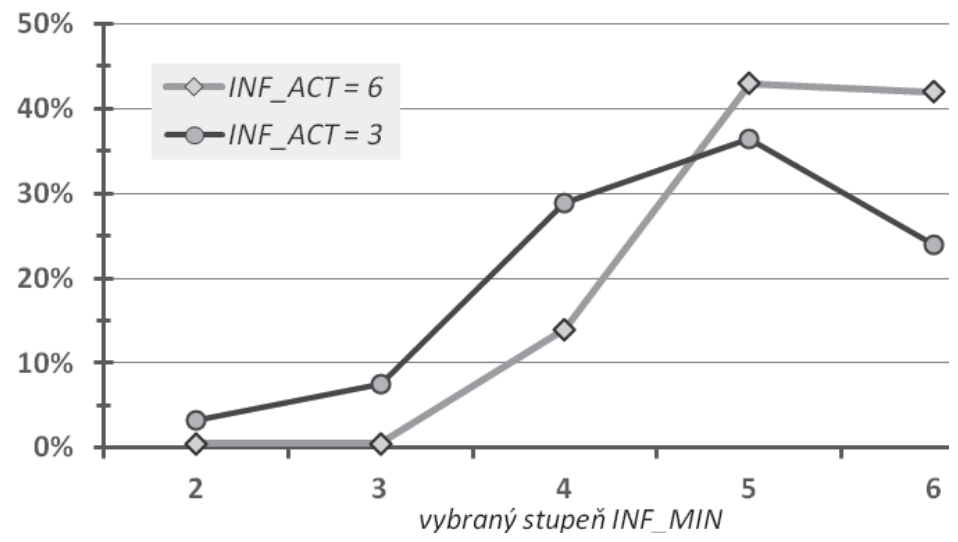

Obrázek 3 Srovnání voleb INF_MIN pro podskupiny dle INF_ACT (VIV13)

Graf zřetelně ukazuje rozdíl v požadavcích na minimální úroveň tak, jak byla formulována výše. Tento jev lze samozřejmě do jisté míry přisoudit relativizaci na škále, avšak výzkumný tým tyto př́čciny spatřuje mimo jiné v relativizaci požadavků (nikoli škály), tj. minimální požadavky jsou chápány částečně jako cíl, který má být splněn v bliže neurčeném časovém horizontu, a proto se do vyjádření respondentů k minimálním požadavkům promítá současná situace jejich školy. 
62 Třetí dílčí dotaz zjišt’oval stupeň ICT kompetencí samotných respondentů (RESP_ $\mathrm{ACT})$. Nejvíce respondentů ( $53 \%$ ) deklaruje současnou úroveň svých kompetencí na pátém stupni škály a třetina respondentů ( $32 \%)$ hodnotí sebe sama stupněm nejvyšším. Naopak 15 \% obsazuje třetí a čtvrtý stupeň, a nedosahuje tedy ani minimální požadované úrovně kompetencí (medián INF_MIN). Podrobnější pohled na tuto problematiku (vztah RESP_ACT a INF_MIN) odhaluje další zajímavé skutečnosti ilustrované v grafu, který pro srovnání prezentuje i obdobná data VIV06 (obrázek 4).

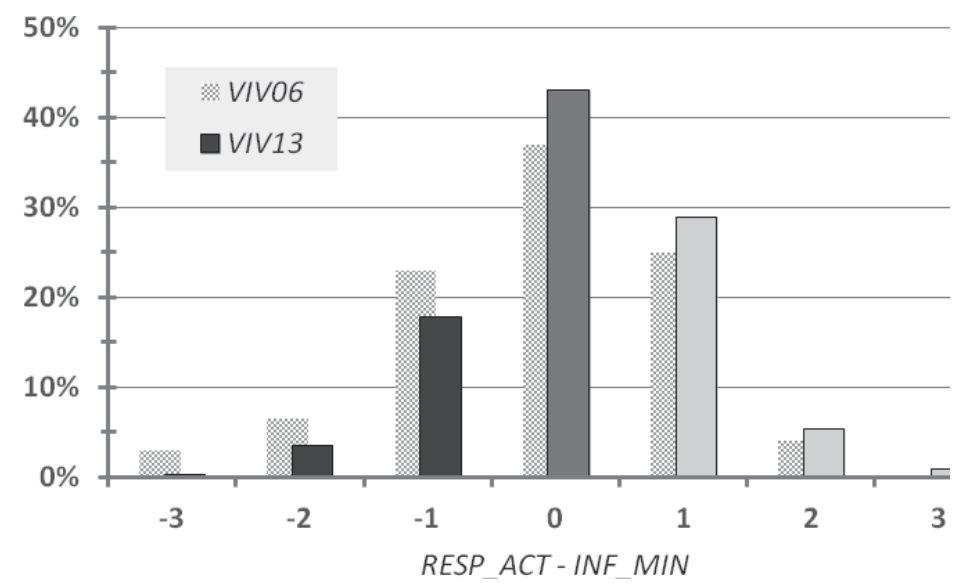

Obrázek 4 Rozložení hodnot konstruktu RESP_ACT - INF_MIN

Graf zobrazuje četnosti, resp. počty respondentů podle zjištěných rozdílů (měřeno stupni škály), současné úrovně kompetencí respondenta (autoevaluace) a jím deklarované minimální požadované úrovně učitele informatických předmětů (rozdíl RESP_ACT - INF_MIN). Vyšší než vlastní volbou požadovanou minimální úroveň deklaruje $35 \%$ (poslední tři sloupce) respondentů a stejnou 43 \% (střední sloupec). Naopak 22 \% respondentů sebe sama hodnotí nižším stupněm, než který považuje za minimálně přijatelný (první tři sloupce). Z toho vyplývá, že více než pětina respondentů nepovažuje své vlastní ICT kompetence za akceptovatelné, resp. dostatečné, pro realizaci výuky informaticky orientovaných předmětů na základní škole. Ve srovnání s výstupy stejné analýzy VIV06 lze však konstatovat, že podíl respondentů deklarujících své kompetence (RESP_ACT) níže než jimi zvolený minimální stupeň (INF_MIN) výrazně poklesl, z $33 \%$ na $22 \%$.

\section{Závěr}

Prezentované výsledky projektu „Informačně technologické kompetence dětí a jejich rozvoj na základních školách" rámcově charakterizují situaci na ZŠ v ČR. Poskytují stručný pohled na klíčové aspekty informačně technologické výchovy na základ- 
ních školách, tj. především na povinné informatické předměty, jejich pojetí a obsah, a dále na učitele, kteří tyto předměty zabezpečují.

Výsledky výzkumu uvedené v tomto článku jsou výběrem zjištění učiněných v rámci první fáze výzkumu (viz Metody a průběh výzkumu). Ve druhé fázi byla řada zjištění doplněna a zpřesněna. Nejdůležitější z nich jsou shrnuta v následujícím přehledu:

1. Stávající pojetí RVP ZV v oblasti Informační a komunikační technologie je většinově považováno za příliš obecné, zastaralé, bez jasné koncepce, nereflektující vývoj v dané oblasti a nové požadavky na rozvoj informačně technologických kompetencí žáků. Požadováno je jeho přepracování z hlediska obsahu i hodinové dotace příslušného předmětu, resp. explicitní integrace digitálních technologií a důraz na rozvoj příslušných kompetencí do ostatních vyučovacích předmětů.

2. Informačně technologická výchova realizovaná v informatických předmětech inklinuje $\mathrm{k}$ zúženému pojetí orientovanému na uživatelské dovednosti, zvládnutí základních, většinou kancelářských, aplikací a vyhledávání informací, které je doplněno o etické, bezpečnostní a právní aspekty.

3. Přestože v praxi škol převládá platformní a aplikační přístup, mnozí učitelé považují za důležité pracovat v různých prostředích, aby rozvoj kompetencí žáků nebyl závislý na konkrétní platformě a konkrétních aplikacích, nebot' bezproblémová adaptace na nové technologie je možná jen tehdy, je-li porozumění žákư založeno na invariantních nadplatformních a nadaplikačních př́stupech.

4. Struktura a rozsah, resp. úroveň informačně technologických kompetencí učitelů informatických předmětů zásadně ovlivňuje pojetí a orientaci informačně technologické výchovy realizované v těchto předmětech. Tematické celky nebo kompetence, které učitelé sami hưře zvládají nebo jsou pro ně náročné, hodnotí jako málo významné pro rozvoj informačně technologických kompetencí žáků na základní škole, a ve výuce se jim proto nevěnují.

5. Implementace digitálních technologií a aktivit podporujících rozvoj informačně technologických kompetencí žáků do vzdělávacího prostředí a života školy se rozvíjí především $v$ těch směrech, které nekladou zvýšené časové nebo odborné nároky na učitele.

Přestože počet respondentů byl poměrně značný (1183) a geografické rozložení respondenty zastoupených škol odpovídalo celkovému rozložení základních škol v České republice, nebyl výběr vzorku z podstaty použitých metod a dobrovolnosti zapojení reprezentativní. Nicméně zejména závěry, které se dotýkají problémů a nedostatků informačně technologické výchovy na našich školách, je třeba chápat jako závažné, i když míru jejich rozšíření není možné spolehlivě určit. 
Ala-Mutka, K. et al. (2008). Digital competence for lifelong learning. Luxembourg: Office for Official Publications of the European Communities.

Ala-Mutka, K. (2011). Mapping digital competence: towards a conceptual understanding. Luxembourg: Publications Office of the European Union.

Anderson, R. (2008). Implications of the information and knowledge society for education. In J. Voogt \& G. Knezek (Eds.), International Handbook of Information Technology in Primary and Secondary Education (s. 5-22). New York: Springer.

Český statistický úrad. (2012). Učitelé na jednotlivých typech a druzích škol podle pohlaví. Dostupné z http: / / www.czso.cz/csu/2012edicniplan.nsf/t/F0003691C7/\$File/1413123302 .pdf.

EuropeanCommission. (2010). A digital agenda for Europe, СОM(2010)245 final. Luxembourg: Office for Official Publications of the European Communities.

European Parliament and the Council. (2006). Recommendation of the European Parliament and of the Council of 18 December 2006 on key competences for lifelong learning. Official Journal of the European Union, 55(L394/10). Luxembourg: Office for Official Publications of the European Communities. Dostupné z http://eur-lex.europa.eu/LexUriServ/LexUriServ .do?uri=OJ:L:2006:394:0010:0018:EN:PDF.

Eurydice. (2002). Key competencies. A developing concept in general compulsory education. Brussels: Eurydice.

Ferrari, A. (2012). Digital Competence in practice: An analysis of frameworks. Luxembourg: EuropeanCommission. Dostupné z http://ftp.jrc.es/EURdoc/JRC68116.pdf.

Hoffman, M., \& Blake, J. (2003). Computer literacy: today and tomorrow. Journal of Computing Sciences in Colleges, 18(5), 221-233.

Neumajer, O. (2007). ICT kompetence učitelů. Praha: Pedagogická fakulta UK.

Peterka, J. (2005). Jak se měří informační gramotnost? Dostupné z http://www.earchiv.cz /b05/b0412001.php3.

Procházka, J. (2007). Realizace interaktivních uspořádacích dotazů na www. In J. Hrbáček (Ed.), Moderní technologie ve výuce (s. 19-23). Brno: Pedagogická fakulta MU.

Rambousek, V. et al. (2007). Výzkum informační výchovy na základních školách. Plzeň: Koniáš.

Rambousek, V., \& Wildová, R. (2008). Contemporary models of new literacy and e-skills. In MEDACTA 2008 (s. 367-378). Nitra: UKF.

Rambousek, V. et al. (2013). Rozvoj informačně technologických kompetencí na základních školách. Praha: ČVUT.

PhDr. Jiří Štípek, Ph.D., Katedra informačních technologií a technické výchovy Univerzita Karlova v Praze, Pedagogická fakulta jiri.stipek@pedf.cuni.cz

Mgr. Petra Vaňková, Katedra informačních technologií a technické výchovy Univerzita Karlova v Praze, Pedagogická fakulta petra.vankova@pedf.cuni.cz 